\title{
Effect of a booster-dose of rabies vaccine on the duration of virus neutralizing antibody titers in bovines
}

\author{
Efeito de uma dose de reforço da vacina anti-rábica sobre a \\ duração de títulos de anticorpos neutralizantes \\ do vírus, em bovinos
}

\author{
Avelino Albas, Paulo Eduardo Pardo, Albério Antonio Barros Gomes, \\ Fernanda Bernardi and Fumio Honma Ito
}

\begin{abstract}
Humoral immune response using inactivated rabies vaccine was studied in 35 nelore cross-bred bovines of western region of São Paulo state. Ninety days after vaccination, 13 (92.8\%) animals presented titers $\geq 0.5 \mathrm{IU} / \mathrm{ml}$, through mouse neutralization test. After 180 days, $9(64.3 \%)$ sera showed titers $\geq 0.5 \mathrm{IU} / \mathrm{ml}$, after 270 days, only one $(7.1 \%)$ showed a titer of $0.51 \mathrm{IU} / \mathrm{ml}$, and after 360 days, all animals showed titers $<0.5 \mathrm{lU} / \mathrm{ml}$. Group of animals receiving booster dose 30 days after vaccination presented, two months after, all with titers $>0.5 \mathrm{IU} / \mathrm{ml}$. At 180 days, $17(80.9 \%)$ sera presented titers > 0.5IU/ml; at 270 days, $15(71.4 \%)$, with titers $\geq 0.5 \mathrm{IU} / \mathrm{ml}$ and at 360 days, 4 $(19.0 \%)$, with titers $\geq 0.5 \mathrm{lU} / \mathrm{ml}$. Booster-dose ensured high levels of neutralizing antibodies for at least three months, and 240 days after revaccination, $71.4 \%$ of animals were found with titers $\geq 0.5 \mathrm{IU} / \mathrm{m} /$.
\end{abstract}

Key-words: Vaccination. Rabies. Bovine. Booster. Neutralizing antibodies.

Resumo A resposta humoral com vacina anti-rábica inativada foi estudada em 35 bovinos mestiços de raça nelore, na região oeste do estado de São Paulo. Noventa dias após a primo-vacinação, 13 $(92,8 \%)$ animais apresentaram títulos $\geq 0,5 \mathrm{Ul} / \mathrm{ml}$, através da prova de soroneutralização em camundongos. Após 180 dias, 9 (64,3\%) soros evidenciaram títulos $\geq 0,5 \mathrm{Ul} / \mathrm{ml}$; após 270 dias, apenas $1(7,1 \%)$ soro demonstrou título = 0,51 $\mathrm{Ul} / \mathrm{ml}$. O grupo que recebeu dose de reforço 30 dias após primo-vacinação apresentou, dois meses depois, 21 animais com títulos > 0,5Ul/ml. Aos 180 dias, 17 (80,9\%) soros apresentaram títulos > 0,5Ul/ml; aos 270 dias, 15 (71,4\%) soros com títulos $\geq 0,5 \mathrm{Ul} / \mathrm{ml}$; aos 360 dias, $4(19,0 \%)$ com títulos $\geq 0,5 \mathrm{Ul} / \mathrm{ml}$. O reforço proporcionou nível elevado de anticorpos, por um período de três meses ou mais e, 240 dias após a revacinação, $71,4 \%$ dos animais apresentou títulos $\geq 0,5 \mathrm{Ul} / \mathrm{ml}$.

Palavras-chaves: Vacinação. Raiva. Bovinos. Dose de reforço. Anticorpos neutralizantes.

Núcleo Regional de Presidente Prudente do Instituto Biológico, Faculdade de Ciências Agrárias da Universidade do Oeste Paulista Presidente Prudente, SP, Universidade Federal da Paraíba, Patos, PB

Departamento de Medicina Veterinária Preventiva e Saúde Animal da Faculdade de Medicina Veterinária e Zootecnia da Universidade de São Paulo, São Paulo, SP.

Address to: Avelino Albas. Núcleo Regional de Presidente Prudente/Instituto Biológico. Caixa Postal 298, $19001-970$ Presidente Prudente, SP, Brasil.

Telefax: (018) 222-8688

Recebido para publicação em 14/07/97. 
Rabies in bovines has been a major concern for Latin American countries, especially in those regions where hematophagous bats are involved 15. Acha 3 and Acha and Malaga-Alba ${ }^{2}$ reported huge economic losses due to rabies.

After vaccination, the presence of rabies neutralizing antibodies at a titer $\geq 1: 5$ could be interpreted as a good indicator of the immune response 6 . For determination of the degree of immunity of human vaccinees, a level of antibodies $\geq 0.5$ International Units $/ \mathrm{ml}$ indicates adequate protection and if titers are $\leq 0.5 \mathrm{IU} / \mathrm{ml}$, booster doses should be administered until antibodies become demonstrable17. Ito et al9 using a commercially available inactivated vaccine prepared in BHK-21 cells, evaluated the blocking effect of antigen due to the presence of rabies specific neutralizing antibodies in previously vaccinated cows; after $72 \mathrm{~h}$ of revaccination the mean neutralizing titer has increased to 1:277 \pm 161 , and $>1: 25,600$ at 14 days postrevaccination. Côrtes et al7, using a BHK cell inactivated vaccine adjuvanted with aluminium hydroxide either alone or in combination with avridine demonstrated the importance of revaccination for the persistence of high levels of antibodies for more than 2 years after revaccination; the protection against challenge made after 12 months from the revaccination reached $90 \%$.

The fact that one has vaccinated the animals does not imply obligatorily that animals will respond with high levels of antibodies, there exists situation of vaccination failures 16 . Albas et al 4 have reported vaccination failure in bovines of the western region of the state of São Paulo and Montano et al10 and Rondon et al14 reported the occurrence of rabies in animals with records of previous vaccination.

In this work, the main objective was directed to assess the effect of booster vaccination made 30 days after the primary vaccination, observing the responses in rabies neutralizing antibodies for a period of one year. Although being an extrapolation of procedures used for humans, titers of neutralizing antibodies were expressed in $\mathrm{IU} / \mathrm{ml}$.

\section{MATERIAL AND METHODS}

Vaccine*. Rabies vaccine used was constituted of a PV virus, BHK -21 clone 13 replicated and

* IRFA - Química e Biotecnologia Industrial Ltda., Porto Alegre, RS, Brasil.
Bromoethileinemine - inactivated vaccine (lot number 001/95, Habel test $=4.9$ ) and adsorbed in aluminum - gel-hydroxide.

Animals. In this experiment, 35 weaned nelore cross-bred, two to five years old in age were vaccinated and had been maintained at Fazenda São José, in Regente Feijó, SP.

Mouse serum neutralization test. The test used was according to Atanasiu5, adopting the 2 - fold serial dilution, and using a Berna international standard serum, lot 137970103 having $200 \mathrm{IU} / \mathrm{ml}$.

Procedures. The animals were separated in 2 groups, a group of 14 animals received a single dose of $2.0 \mathrm{ml}$ through subcutaneous route, and the other group of 21 animals received 2 doses, the booster injection was administered 30 days after the first dose. The group of 14 animals was bled at day zero, i.e., immediately before the administration of the first dose of vaccine and at each 3 - month interval for a period of one year. The other group of 21 animals were bled similarly at day 0 and at two months of the primary vaccination and then at each 3 - month interval, until 360 days. Serum samples were kept frozen in aliquots of $2 \mathrm{ml}$ and stored until use. For statistical analysis, individual titers $(x)$ in IU values were submitted to logarithmic transformation, using $\log _{10}(x+1)$ and then analyzed by ANOVA and unpaired test, using $\alpha=0.0512$.

\section{RESULTS}

The results of serum neutralization test of the group of animals that received a single dose of vaccine are summarized in Table 1 . At day 0 , all sera tested were found without rabies neutralizing antibodies. At day 90 after primary vaccination, $13(92.8 \%)$ of animals presented varied levels of serum neutralizing titers $\geq 0.5 \mathrm{IU} / \mathrm{ml}$ and 1 animal did not respond to vaccination. After 180 days, sera of $9(64.3 \%)$ animals were found with titers $\geq 0.5 \mathrm{IU} / \mathrm{ml}$, and after 270 days, only one serum $(7.1 \%)$ was still found with a titer of $0.51 \mathrm{IU} / \mathrm{ml}$, and after 360 days, all animals were detected with serum neutralizing titers $<$ than $0.5 \mathrm{IU} / \mathrm{ml}$.

The results of neutralization test corresponding to the group of animals that recieved a booster dose 30 days after the primary vaccination are presented in Table 2. At day 0 all animals did not present any detectable levels of rabies neutralizing antibodies. Two months after receiving the booster dose, all 21 animals were found with neutralizing 
Table 1 - Results of mouse serum neutralization test performed on sera of bovines vaccinated with a single dose and without a booster injection.

\begin{tabular}{llllll}
\hline Animal & \multicolumn{5}{c}{ Time in days } \\
\cline { 2 - 6 } & 0 & 90 & 180 & 270 & 360 \\
\hline 1 & 0 & 1.12 & 0.57 & 0.0 & 0.0 \\
2 & 0 & 0.50 & 0.0 & 0.0 & 0.0 \\
3 & 0 & 1.26 & 0.52 & 0.45 & 0.45 \\
4 & 0 & 0.50 & 0.32 & 0.0 & 0.0 \\
5 & 0 & 0.57 & 0.51 & 0.0 & 0.0 \\
6 & 0 & 0.50 & 0.0 & 0.0 & 0.0 \\
7 & 0 & 1.74 & 0.53 & 0.51 & 0.40 \\
8 & 0 & 1.50 & 0.50 & 0.0 & 0.0 \\
9 & 0 & 0.87 & 0.53 & 0.16 & 0.0 \\
10 & 0 & 0.50 & 0.50 & 0.19 & 0.0 \\
11 & 0 & 0.69 & 0.0 & 0.0 & 0.0 \\
12 & 0 & 1.34 & 0.53 & 0.10 & 0.0 \\
13 & 0 & 0.0 & 0.0 & 0.14 & 0.0 \\
14 & 0 & 0.69 & 0.52 & 1.111 & 0.0 \\
\hline geometric mean titer & 1.0 & 1.841 & 64.3 & 7.1 & 1.061 \\
$\%$ titer $\geq 0.5 \mathrm{IU} / \mathrm{ml}$ & 0.0 & 92.8 & & 0.0
\end{tabular}

titers in IU/ml.

$\mathrm{SN}$ titers $<2$ were considered as having $0 \mathrm{IU} / \mathrm{ml}$.

for statistical analysis, transformation of $\log _{10}(x+1)$ was used.

Table 2 - Results of mouse serum neutralization test performed on sera of bovines revaccinated with a booster injection 30 days after the primary vaccination.

\begin{tabular}{|c|c|c|c|c|c|}
\hline \multirow[t]{2}{*}{ Animal } & \multicolumn{5}{|c|}{ Time in days } \\
\hline & 0 & 90 & 180 & 270 & 360 \\
\hline 1 & 0 & 10.20 & 0.81 & 0.77 & 0.64 \\
\hline 2 & 0 & 11.70 & 0.52 & 0.50 & 0.32 \\
\hline 3 & 0 & 0.56 & 0.60 & 0.31 & 0.0 \\
\hline 4 & 0 & 5.10 & 0.90 & 0.64 & 0.10 \\
\hline 5 & 0 & 1.36 & 0.55 & 0.52 & 0.32 \\
\hline 6 & 0 & 3.06 & 0.60 & 0.28 & 0.0 \\
\hline 7 & 0 & 3.76 & 0.51 & 0.50 & 0.32 \\
\hline 8 & 0 & 1.09 & 0.61 & 0.51 & 0.47 \\
\hline 9 & 0 & 8.96 & 0.88 & 0.64 & 0.51 \\
\hline 10 & 0 & 1.92 & 0.61 & 0.51 & 0.38 \\
\hline 11 & 0 & 13.40 & 0.51 & 0.51 & 0.45 \\
\hline 12 & 0 & 1.30 & 0.0 & 0.0 & 0.0 \\
\hline 13 & 0 & 2.85 & 0.55 & 0.50 & 0.50 \\
\hline 14 & 0 & 1.79 & 0.64 & 0.52 & 0.37 \\
\hline 15 & 0 & 47.90 & 0.80 & 0.55 & 0.50 \\
\hline 16 & 0 & 9.58 & 0.56 & 0.61 & 0.0 \\
\hline 17 & 0 & 16.50 & 0.72 & 0.80 & 0.44 \\
\hline 18 & 0 & 0.53 & 0.0 & 0.0 & 0.0 \\
\hline 19 & 0 & 0.53 & 0.0 & 0.0 & 0.0 \\
\hline 20 & 0 & 0.51 & 0.50 & 0.32 & 0.0 \\
\hline 21 & 0 & 6.80 & 0.76 & 0.67 & 0.35 \\
\hline geometric mean titer & 1.0 & 8.114 & 1.554 & 1.460 & 1.270 \\
\hline$\%$ titer $<0.5 \mathrm{IU} / \mathrm{ml}$ & 0.0 & 100 & 80.9 & 71.4 & 19.0 \\
\hline
\end{tabular}

titers in IU/ml.

$\mathrm{SN}$ titers $<2$ were considered as having $0 \mathrm{IU} / \mathrm{ml}$.

for statistical analysis, transformation of $\log _{10}(x+1)$ was used. 
titers $>0.5 \mathrm{IU} / \mathrm{ml}$, and at 180 days, $17(80.9 \%)$ sera were found with titer $>0.5 \mathrm{IU} / \mathrm{ml}$, and $1(4.8 \%)$ with titer $=0.5 \mathrm{IU} / \mathrm{ml}$ and $3(14.3 \%)$ sera $<0.5 \mathrm{IU} / \mathrm{ml}$; at 270 days, $15(71.4 \%)$ sera were found with titers $\geq 0.5 \mathrm{IU} / \mathrm{ml}$ and at 360 days, only $4(19.0 \%)$ sera were found with titers $\geq 0.5 \mathrm{IU} / \mathrm{ml}$.

Statistical analysis showed for a group of vaccinated animals an extremely significant $(p<0.001)$ when results of day 0 were compared to day 90 , similarly, the result of comparison was significant between days 90 and 180 $(p<0.001)$. After this period, statistical analyses were not significant $(p>0.05)$. Similarly, group of revaccinated animals presented significant result $(p<0.001)$ between days 0 and 90 and for days 90 and 180 . Forward to this period, there was a decrease in antibody titers, indicating non significant results $(p>0.05)$. The unpaired t test indicated no statistical difference between the results of day 180 of both vaccinated and revaccinated group.

\section{DISCUSSION}

The animals used in this experiment were not found with any detectable rabies antibody titers at day 0 , indicating that they were probably not vaccinated. In the group that received a single dose of vaccine, one animal did not show a detectable level of antibodies through the entire experiment; this unresponsiveness to vaccination could be related to the host. For this group, the response in antibody formation has decreased after 180 days. Animals receiving a booster dose presented a more persistent and higher levels of antibody response profile, the decrease in its titers occurred between 90 and 180 days. In this group, 3 animals have responded with low titers through the whole experiment, detectable titers were found only at day 90 , respectively with $1.30 ; 0.53$ and $0.53 \mathrm{IU} / \mathrm{ml}$. If a titer of $\geq 0.5 \mathrm{IU} / \mathrm{ml}$ is considered to be protective in bovines, all vaccinated animals needed to be revaccinated before reaching 270 days and the majority $(81 \%)$ of revaccinated animals did not maintain the immunity for one year.

In several experiments using antirabies vaccines, responses were varied, but in almost all experiments, the patterns in antibody responses most frequently reported is that initially there occurs a rapid rise in neutralizing titers, but after 90 to 180 days, there is a fast decrease, but still maintaining a detectable level1 6811 13. Côrtes et al7 used an inactivated rabies vaccine, adjuvanted with aluminum hydroxide either alone or combined with avridine, and recommended that booster vaccination could be administered six months after the first vaccination. Results found in this experiment showed the same pattern of antibody response, being markedly high around 90 days and rapidly decreasing to values between 0.5 and $1.01 \mathrm{U} / \mathrm{ml}$, for the group given the booster-dose. The ANOVA test indicated that after 270 and 360 days, levels of neutralizing antibodies were not different from day 0 for group of animals that received a single dose of vaccine. For revaccinated animals, similar results were found, i.e., no differences were found between 0 and 270 days, and 0 and 360 days, indicating that marked decrease in antibody levels occurred after 90 days of vaccination and at 180 and 270 days, 80.9 and $71.4 \%$ respectively presented titers $\geq 0.5 \mathrm{IU} / \mathrm{ml}$. The effective protection, however, one can only determine if controlled challenge experiment is used. With the vaccine used in this experiment, booster-dose given 30 days after the primary vaccination has ensured levels of neutralizing antibodies $\geq 0.5 \mathrm{IU} / \mathrm{ml}$ for a period of at least three months or more (until the day 270 ) to a majority of animals.

\section{REFERENCES}

1. Abelseth MK. Propagation of rabies virus in pig kidney cell culture. Canadian Veterinary Journal 5:8487, 1964.

2. Acha PN, Malaga Alba, A. Economic losses due to Desmodus rotundus. In: Greenhall AM, Schmidt U (eds) Natural history of vampires bats, CRC Press Inc., Boca Raton, p.207-214, 1988.

3. Acha PN. Epidemiology of paralytic bovine rabies and bat rabies.Bulletin de l'Office International des Epizooties 67:343-382, 1967.

4. Albas A, Alberti H, Alberti ALL, Pardo PE, Giometti J. Ausência de resposta imune em bovinos vacinados contra a raiva na região de Presidente Prudente, SP, Brasil. A Hora Veterinária 15:64, 1995.

5. Atanasiu, P. Titulación y prueba de potencia del suero y la inmunoglobulina antirrábicos. In: La Rabia, tecnicas de laboratorio, 4th edition, Organización Mundial de la Salud, Ginebra, p.332-336, 1976.

6. Atanasiu P, Fuenzalida E, Acha P, Szyfres B. Inmunidad antirrabica en bovinos vacunados. Revista Veterinaria Venezolana 24:318-334, 1968.

7. Côrtes JA, Rweyemamu MM, Ito FH, Umehara O, Medeiros Neto RR, De Lucca Neto D, Baltazar MC, Vasconcellos SA, Vasconcellos MEP. Immune 
response in cattle induced by inactivated rabies vaccine adjuvanted with aluminium hydroxide either alone or in combination with avridine. Revue Scientifique et Technique. Office International des Épizooties 12:941-955, 1993.

8. Fabrega F, Fuenzalida E, Rodrigues R. Estudio de los anticuerpos neutralizantes en el suero sanguineo de bovinos tratados con vacuna antirrabica. Zooiatria 6:1-4, 1965.

9. Ito $\mathrm{FH}$, Côrtes JA, Rweyemamu MM, Umehara $\mathrm{O}$, Medeiros Neto R, De Lucca Neto D, Baltazar MC, Vasconcellos SA, Vasconcellos MEP. Course Of Humoral Immune response shortly after revaccination with BHK-21 cell culture inactivated rabies vaccine adjuvanted with aluminum hydroxide.Brazilian Journal of Veterinary Research and Animal Science, São Paulo 28:51-57, 1991.

10. Montano JA, Polack GW, Mora FE. Raiva bovina em animais vacinados. II. Situação epidemiológica no estado do Paraná, Brazil - 1984. Arquivos de Biologia e Tecnologia 30:367-380, 1987.

11. Preto AA, Fernandes MJ, Hayashi Y, Germano PML, Burer SP. Preparação de vacina anti - rábica $\mathrm{PV} / \mathrm{BHK}$ em emulsão oleosa e avaliação do poder imunogênico em bovinos. Arquivos de Biologia e
Tecnologia 34:609-616, 1991.

12. Remington RD, Shork MA. Statistics with applications to the biological and health sciences. Prentice - Hall, Englewood Clifs, 1970.

13. Ribeiro Netto A, Nilsson MR, Côrtes JA, Mizuno M, Miguel O. Comparative study of cattle antirabies vaccines. Zentralblat für Veterinarmedizin (B) 20:398404, 1973.

14. Rondon ES, Bastos PV, Silva DA, Piccinini RS. Estudo comparativo da sintomatologia clínica de bovinos suspeitos de raiva. Revista Brasileira de Medicina Veterinária 17:253, 1995.

15. Tadei VA, Gonçalves CA, Pedro WA, Tadei WJ, Kotait I, Arieta C. Distribuição do morcego vampiro Desmodus rotundus (Chiroptera Phyllostomidae) no estado de São Paulo e a raiva dos animais domésticos. Impresso Especial CATI, Campinas, SP, 107,1991.

16. Tizard IR. An introduction to veterinary immunology. W.B. Saunders, Philadelphia, 1977.

17. World Health Organisation Expert Committee on Rabies. Eighth report. World Health Organization, Geneva, (WHO Technical Report Series, no 824), 1992. 